\title{
МОРФООЗНАКИ РОСЛИН ТА РОЗМІРНА СТРУКТУРА ЦЕНОПОПУЛЯЦЙ CENTAURIUM ERYTHREA НА ЗАПЛАВНИХ ЛУКАХ КРОЛЕВЕЦЬКО-ГЛУХІВСЬКОГО ГЕОБОТАНІЧНОГО РАЙОНУ
}

\section{Зубцова І. В., Скляр В. Г.}

\section{ВСТУП}

Сьогодні, незважаючи на активний розвиток традиційної медицини, у світі постійно зростає попит на лікарські рослинні препарати ${ }^{1}$. Їх застосовує близько $80 \%$ населення Землі ${ }^{2} .3$ іншого боку, використання лікарських рослин у майбутньому може бути істотно обмежено у зв'язку 3 проблемою зниження біорізноманітності ${ }^{3,4}$. Це вказує на актуальність розроблення питань, пов'язаних не лише 3 ефективним лікарським застосуванням рослин із цілющими властивостями, а й забезпеченням їх охорони та сталого і довготривалого функціонування популяцій ${ }^{5,6,7}$. Вирішення цього питання у свою чергу потребує проведення ретельних досліджень, спрямованих на вивчення стану провідних лікарських рослин у різних регіонах та умовах місцезростань.

В Україні до числа регіонів, що вирізняються значним видовим i ценотичним різноманіттям та $є$ перспективними в аспекті розширення експлуатації ресурсів лікарських рослин, належить КролевецькоГлухівський геоботанічний район (рис. 1) загалом та його заплавні луки зокрема, що сформовані вздовж річок Сейм, Клевень, Есмань, Реть та ін. ${ }^{8}$

Важливою складовою частиною фіторізноманіття заплавних лук Кролевецько-Глухівського геоботанічного району $є$ цінна лікарська рослина золототисячник звичайний (Centaurium erythrea Rafn.). Ця трав'яниста рослина ${ }^{9}$ відноситься до родини Тирличевих (Gentianaceae).

\footnotetext{
${ }^{1}$ Joy P.P., Thomas J., Mathew S. Medicinal plants. Tropical horticulture. 2001. V. 2. P. 449-632.

${ }^{2}$ Medicinal plants research in Asia. Volume 1. The framework and project workplans (Pons B.A., Kanniah J., Young L.S. et al., eds.). International plant genetic resources institute-Regional office for Asia and Oceania (IPGRI-APO). Serdang, Selangor DE, Malaysia, 2004.

${ }^{3}$ Коропачинский И.Ю. Роль ботанических садов в охране биологического разнообразия России. Сиб. экол. журн. 1997. Т.4. № 1. С. 7-12.

${ }^{4}$ Прохоров А. А. Экологические проблемы сохранения биологического разнообразия на примере генетических ресурсов ботанических садов России: Автореф. дис. докт. биол. наук. Петрозаводск, 2004. 46 c.

${ }^{5}$ Fabricant DS, Farnsworth NR. The value of plants used intraditional medicine for drug discovery. Environ HealthPerspect. 2001. Vol. 109, P. 69-75

${ }^{6}$ Yarnell E, Abascal K. Dilemmas of traditional botanicalresearch. Herbal Gram. 2002. № 55. P. 46-54.

7 Liu WJH. Traditional Herbal Medicine Research Methods:Identification, Analysis, Bioassay, and Pharmaceutical andClinical Studies. N.J.:John Wiley Sons Inc; 2011. 488 p.

8 Заповідні скарби Сумщини / за ред. Т.Л. Андрієнко. Суми: Джерело, 2001. 208 с.

${ }^{9}$ Сикура И.И., Антонюк Н.Е., Пироженко А.А. Интродуцированные лекарственные растения / Под ред. А.М. Гродзинского. 1983. Київ, С. 54-60.
} 
Вона містить алкалоїди, гіркі глікозиди, флавоноїди, ксантони ${ }^{10}$. Виявляє антимутагенну та радіопротекторну дію, слугує компонентом лікувальних зборів при цукровому діабеті, гіпертензії, гінекологічних захворюваннях, алкоголізмі, причому побічної дії препаратів на організм не виявлено ${ }^{11}$.

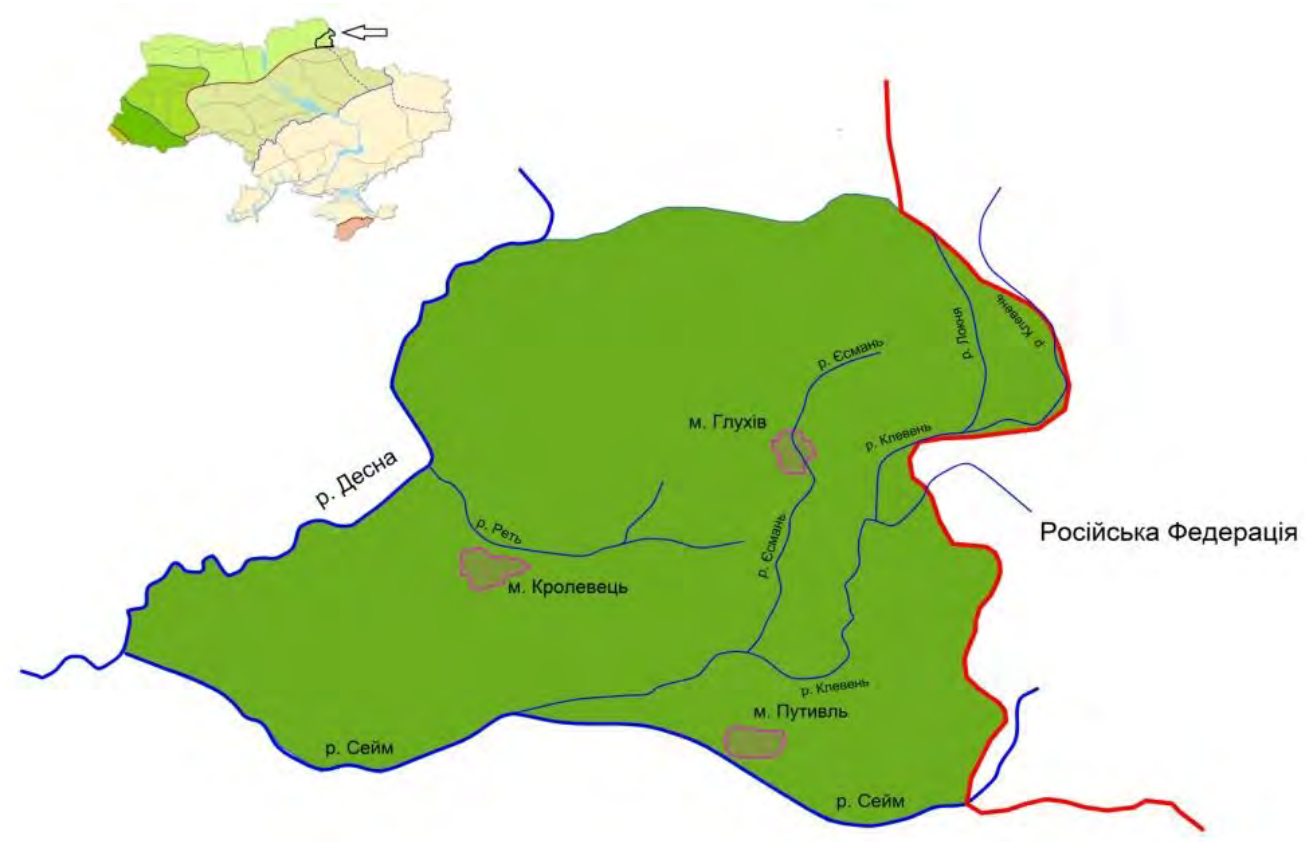

\section{Рис. 1. Карта-схема розташування регіону досліджень}

Натепер результатами досліджень низки різних ценозоутворюючих видів рослин ${ }^{12}$, у тому числі й тих, яким притаманні цілющі властивості ${ }^{13}$, доведено, що сталість та довготривалість існування популяцій значною мірою визначається їхньою розмірною структурою та величинами морфоознак рослин, які входять до їхнього складу ${ }^{14,}$ 15, 16, 17.

\footnotetext{
${ }^{10}$ Товстуха Є.С. Фітотерапія. Київ. 1990 С. 68-69.

${ }_{11}^{11}$ Атлас ареалов и ресурсов лекарственных растений СССР. М.: ГУГК, 1980. С. 243.

${ }^{12}$ Skliar V., Sherstuk M. Size structure of phytopopulations and its quantitative evaluation. Eureka: Life Sciences. 2016. № 1. P. 9-15.

${ }^{13}$ Zubtsova I., Penkovska L., Skliar V., Skliar Yu. Dimensional features population of some species medicinal plants in conditions of northern Eastern Ukraine. AgroLife Journal. 2019. № 8 (2), 191-201.

${ }^{14}$ Шерстюк М.Ю. Ценопопуляції Ledum palustre (Ericaceae) у лісових і лісоболотних фітоценозах Новгород-Сіверського Полісся. Украӥнський ботанічний журнал. 2017. Т. 74. № 1. С. 37-44.

${ }^{15}$ Шерстюк М.Ю. Морфометричні ознаки Oxycoccus palustris Pers. у болотних та лісоболотних фітоценозах Українського Полісся. Науковий вісник Східноєвропейського наиіонального університету імені Лесі Українки. Серія: Біологічні науки. 2016. № 7 (332). С. 78-83.

16 Шерстюк М.Ю., Попович С.Ю. Заповідні дендросозоавтохтони Українського Полісся: монографія. Київ: ЦП Компринт, 2018. 272 с.

${ }^{17}$ Скляр В.Г. Розмірна структура деревостанів сосни звичайної в лісах Новгород-Сіверського Полісся. Ученые записки Таврического национального ун-та им. В. И. Вернадского (Серия «Биология, химия»). 2011. Т. 24 (63), № 4. С. 292-302.
} 
Однак популяції Centaurium erythrea до цього часу ще не були охопленні таким вивченням.

Мета даної публікації - оцінити величини комплексу провідних морфометричних параметрів рослин Centaurium erythrea, які зростають на заплавних луках Кролевецько-Глухівського геоботанічного району, та визначити провідні ознаки розмірної структури популяцій Centaurium erythrea у різних умовах місцезростань.

\section{1. Методи досліджень}

В основу представленої роботи покладені матеріали польових досліджень, проведених на території Кролевецько-Глухівського геоботанічного району протягом 2014-2019 рр. Популяції Centaurium erythrea, які були охоплені вивченням, зростають у різних фітоценозах і за своїми ознаками відповідають категорії «ценопопуляції», однак у тексті роботи для стислості викладення матеріалу використано термін «популяції».

3 метою встановлення стану, структури рослинних угруповань із популяціями Centaurium erythrea були використані загальноприйняті геоботанічні підходи, насамперед метод пробних ділянок. 3 метою отримання репрезентативного матеріалу у фітоценозах закладали декілька облікових ділянок розміром 10 м х 10 м, на яких здійснювали повний геоботанічний опис ${ }^{18,19,20}$.

3 метою визначення розмірних параметрів рослин було застосовано морфометричний аналіз. Для цього у фітоценозах за випадковою схемою відбирали 25-50 рослин Centaurium erythrea. У них оцінювали низку статичних метричних (отримуються в результаті простих вимірювань кількості, ваги чи розміру) та статичних алометричних (відображають співвідношення між тими чи іншими розмірними характеристиками особин) показників ${ }^{21,22,23,24}$ (табл. 1, 2). Виявлені за результатами морфометричних досліджень характерні ознаки габітусу рослин кожної популяції було проілюстровано морфограмами.

Розмірна структура популяцій була встановлена 3 опорою на два морфопараметри (загальну площу листкової поверхні (А) та висоту $(\mathrm{H})$ ) на основі використання оригінальної методики, яка супроводжувалася реалізацію такого алгоритму дій:

\footnotetext{
${ }^{18}$ Полевая геоботаника. М.-Л.: Наука, 1964. Т. 3. 530 с.

${ }^{19}$ Методы полевого изучения лекарственных растений / Кашин А.С. и др. : учебно-метод. пособие для студентов биологического факультета. Саратов, 2007. 27 с.

${ }^{20}$ Якубенко Б.С., Григора I.М. Популяція і фітоценоз. Методи вивчення популяцій. К.: НАУ, 2003. 35 с.

${ }^{21}$ Карманова И.В. Математические методы изучения роста и продуктивности растений. М.: Наука, 1976. 222 c.

${ }^{22}$ Hunt R. Plant growth analysis. London: Arnold, 1978. 67 p.

23 Злобин Ю.А. (а). Принципы и методы изучения ценопопуляций растений. Казань, 1989. 146 с.

24 Злобин Ю.А. Популяционная экология растений: современное состояние, точки роста. Сумы: Университетская книга, 2009. 263 с.
} 
Таблиця 1

Перелік статичних метричних морфопараметрів, що були використані для оцінки стану рослин досліджуваних видів

\begin{tabular}{|l|c|c|}
\hline \multicolumn{1}{|c|}{ Назва морфопараметра } & $\begin{array}{c}\text { Умовні } \\
\text { позначення }\end{array}$ & $\begin{array}{c}\text { Одиниця } \\
\text { виміру }\end{array}$ \\
\hline Загальна маса рослини & $\mathrm{W}$ & $\Gamma$ \\
\hline Загальна маса вегетативних органів & $\mathrm{Wveg}$ & г \\
\hline Загальна фітомаса листків & $\mathrm{WL}$ & г \\
\hline Фітомаса стебла & $\mathrm{Wst}$ & $\Gamma$ \\
\hline Фітомаса одного листка & $\mathrm{WL} 1$ & $\Gamma$ \\
\hline Загальна площа поверхні листків & $\mathrm{A}$ & $\mathrm{cm}^{2}$ \\
\hline Площа одного листка & $\boldsymbol{a}$ & $\mathrm{cm}^{2}$ \\
\hline Загальна кількість листків & $\mathrm{NL}$ & шт. \\
\hline Кількість бічних пагонів першого порядку & $\mathrm{B}$ & шт. \\
\hline Висота рослини & $\mathrm{H}$ & $\mathrm{cm}$ \\
\hline Діаметр стебла & $\mathrm{D}$ & $\mathrm{cm}$ \\
\hline Загальна маса репродуктивних органів & $\mathrm{Wgen}$ & г \\
\hline Маса одного репродуктивного органу & Wgen1 & г \\
\hline Загальна кількість генеративних органів & Ngen & шт. \\
\hline
\end{tabular}

Таблиця 2

Перелік статичних алометричних морфопараметрів, які були використані для оцінки стану рослин досліджуваних видів

\begin{tabular}{|l|c|c|}
\hline \multicolumn{1}{|c|}{ Назва морфопараметра } & $\begin{array}{c}\text { Умовні позначення та } \\
\text { розрахункові формули } \\
\text { морфопараметрів }\end{array}$ & $\begin{array}{c}\text { Одиниця } \\
\text { виміру }\end{array}$ \\
\hline $\begin{array}{l}\text { Площа листків на одиницю } \\
\text { фітомаси }\end{array}$ & $\mathrm{LAR}=\mathrm{A} / \mathrm{W}$ & $\mathrm{cm}^{2} / \Gamma$ \\
\hline Фотосинтетичне зусилля & $\mathrm{LWR}=\mathrm{WL} / \mathrm{W}$ & $\Gamma / \Gamma$ \\
\hline Відносний приріст & $\mathrm{HWR}=\mathrm{H} / \mathrm{W}$ & $\mathrm{cm} / \Gamma$ \\
\hline $\begin{array}{l}\text { Відношення загальної площі } \\
\text { листків до діаметра стебла }\end{array}$ & $\mathrm{ADR}=\mathrm{A} / \mathrm{D}$ & $\mathrm{cm}^{2} / \mathrm{Mm}$ \\
\hline $\begin{array}{l}\text { Співвідношення між висотою } \\
\text { рослини та діаметром стебла }\end{array}$ & $\mathrm{HDR}=\mathrm{H} / \mathrm{D}$ & $\mathrm{cm} / \mathrm{cm}$ \\
\hline Репродуктивне зусилля & $\mathrm{RE} 1=(\mathrm{Wgen} / \mathrm{W}) \times 100$ & $\%$ \\
\cline { 2 - 3 } & $\mathrm{RE} 2=(\mathrm{Wgen} / \mathrm{A}) \times 100$ & $\%$ \\
\hline
\end{tabular}

1. Для всієї сукупності особин визначено мінімальні та максимальні значення Н та А;

2.3 урахуванням мінімальних та максимальних величин вибраних морфопараметрів для кожного з них було визначено класи розмірності; 
3. Складена матриця класів розмірності;

4. У популяції визначено положення кожної рослини в полі матриці;

5. Для популяції оцінено відсоток особин, котрі репрезентують різні класи розмірності;

6. Для популяції визначено величину IDSS за В.Г. Скляр ${ }^{25}$ :

$$
\operatorname{IDSS}=(\mathrm{Nf} / \mathrm{Nt}) * 100 \%,
$$

де $N f$ - кількість сполучень різних розмірних класів А та $\mathrm{H}$, що виявлені в рослині певної популяції; $N t$ - теоретично розрахована кількість можливих сполучень у рослин розмірних класів А та Н.

\section{2. Результати досліджень та їх обговорення}

Результати оцінки розмірних величин рослин Centaurium erythrea наведено в таблиці 3. Для абсолютної більшості розмірних величин зареєстровані відмінності у величинах морфопараметрів у рослин із різних угруповань, що є статистично достовірними. Винятком є лише показник кількості бічних пагонів.

Досліджувані морфопараметри демонструють свої особливості щодо змін величин за досліджуваними фітоценозами (рис. 2). Разом із тим їм притаманний і прояв певних загальних тенденцій. Найбільші значення значної частки морфопараметрів (дев'яти із 21, охоплених вивченням) припадають на популяцію 3 угруповання Trifolietum (repentis) tanacetosum (vulgaris). Навпаки, в популяції з угруповання Trifolietum (pratensis) elytrigiosum (repentis) зареєстровано найменші показники 13 розмірних величин.

У підсумку характерною ознакою рослин Centaurium erythrea 3 угруповання Trifolietum (repentis) tanacetosum (vulgaris) $€$ те, що порівняно з рослинами інших популяцій вони мають найбільші значення комплексу показників, які характеризують вагу рослин та їхніх окремих органів (загальну масу рослин $(\mathrm{W}=8,86 \pm 0,567$ г), масу вегетативних

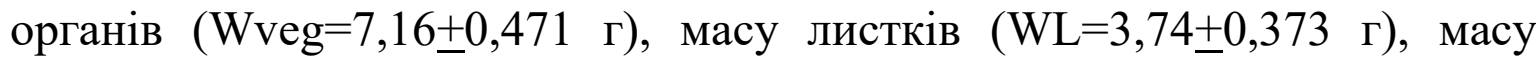
стебла (Wst=3,11 $\pm 0,122$ г), масу одного листка (WL1 $=0,30 \pm 0,021$ г), а також площу листкової поверхні $\left(\mathrm{A}=28,16 \pm 1,980 \mathrm{~cm}^{2}\right)$, кількість листків $(\mathrm{NL}=12,26 \pm 0,529$ шт.), діаметр стебла $(\mathrm{D}=0,09 \pm 0,002$ см), фотосинтетичне зусилля $(\mathrm{LWR}=0,41 \pm 0,020$ г/г). Разом із тим рослини із цього угруповання $\epsilon$ найменш розгалуженими $(\mathrm{B}=2,33 \pm 0,232$ шт.) та мають найменші величини співвідношення між висотою та фітомасою $(\mathrm{HWR}=3,27 \pm 0,252 \mathrm{~cm} / \Gamma)$ (рис. 3 ).

${ }^{25}$ Скляр В.Г. Узагальнюючі моделі вертикальної структури деревостанів лісових фітоценозів Лівобережного Полісся України. Вісник Запорізького національного університету. Біологічні науки. 2016. № 1. C. 176-184. 
Current effect: $F(5,84)=8,3375, p=, 00000$

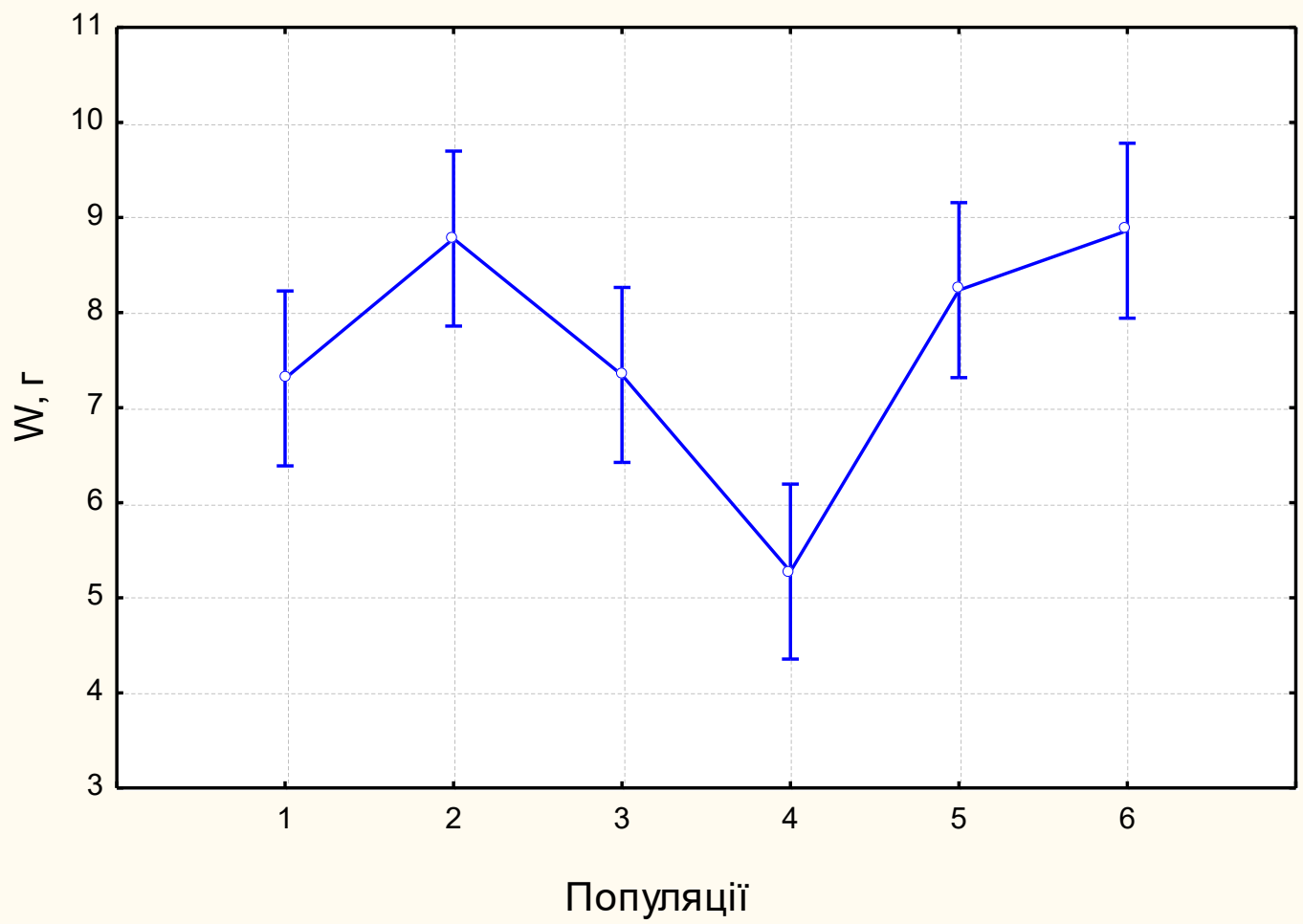

A

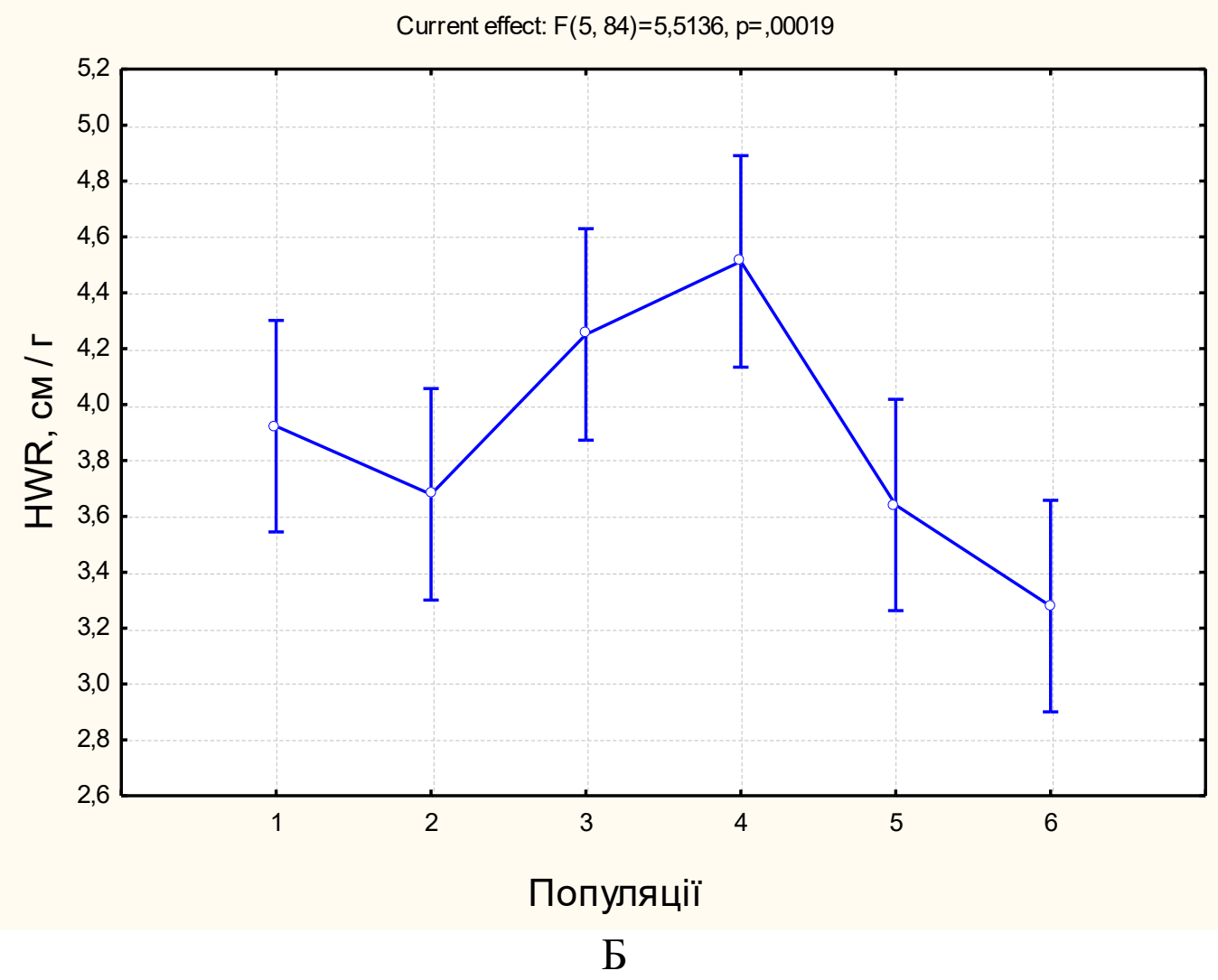

Рис. 2. Зміна величин середніх значень загальної фітомаси рослин (А) та відносного приросту (Б) за популяціями Centaurium erythrea 


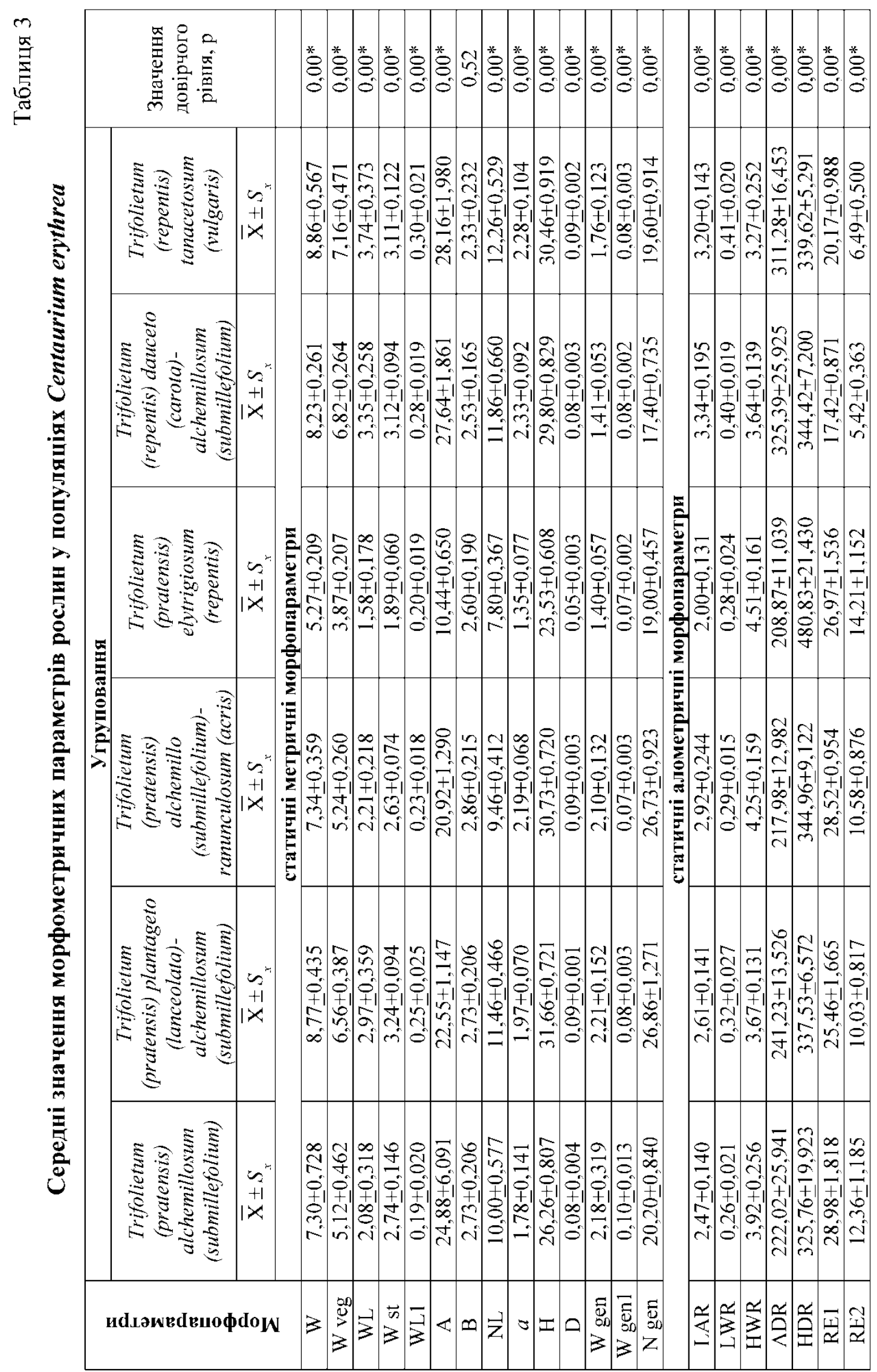



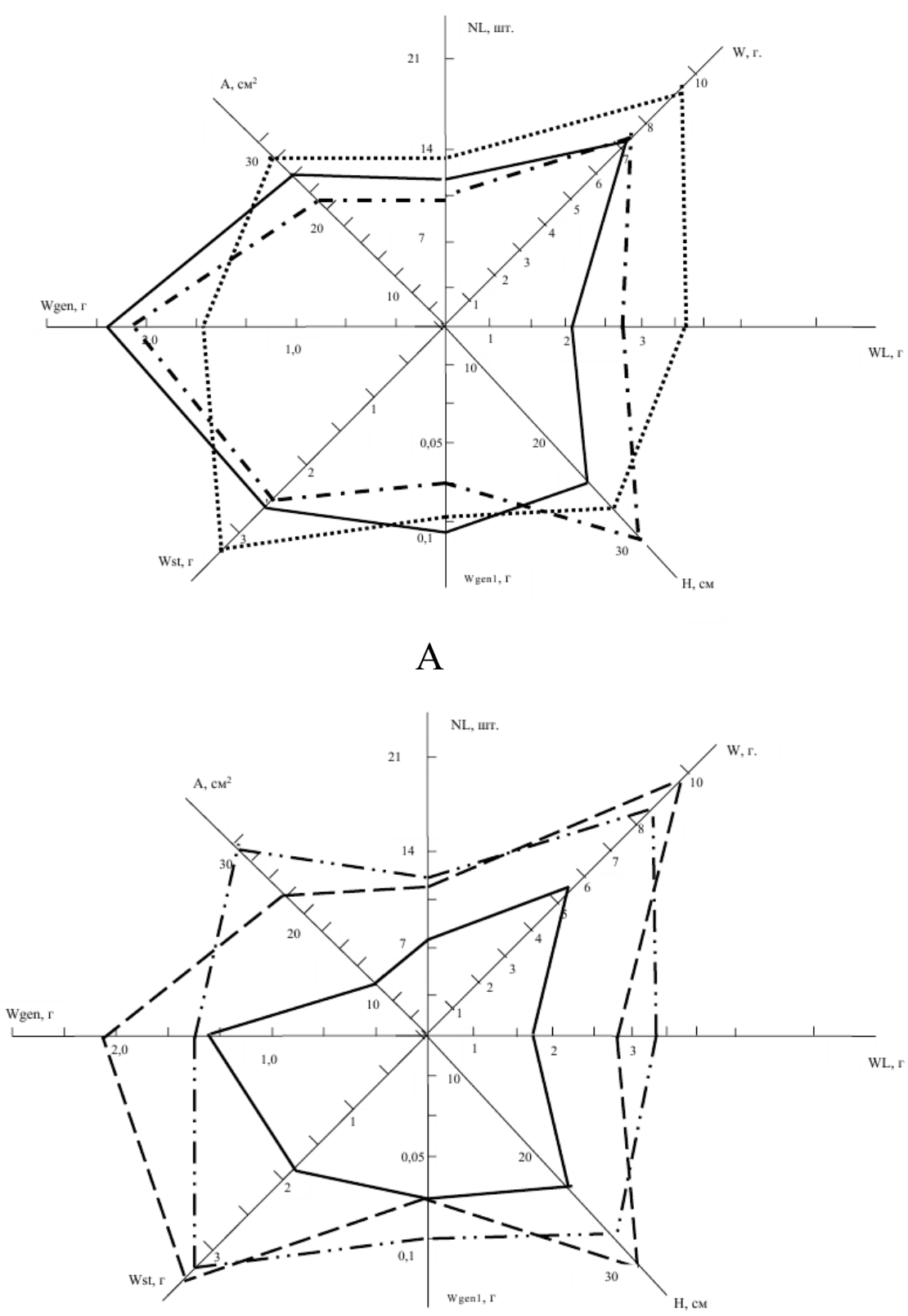

Б

Рис. 3. Морфограми рослин Centaurium erythrea досліджуваних популяцій (умовні позначення морфопараметрів відповідають наведеним у таблицям 1, 2). На рисунку зображено популяції з угруповань:

A

....... Trifolietum (repentis) tanacetosum (vulgaris),

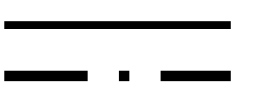

Trifolietum (pratensis) alchemillosum (submillefolium),

Б

Trifolietum (pratensis) alchemillo (submillefolium) - ranunculosum (acris).

Trifolietum (repentis) dauceto (carota)-alchemill
Trifolietum (pratensis) elytrigiosum (repentis),

(submillefolium).

Trifolietum (pratensis) plantageto (lanceolata)-alchemillosum 
Рослини з угруповання Trifolietum (pratensis) plantageto (lanceolata)alchemillosum (submillefolium) вирізняються тим, що є найбільшими за висотою $(\mathrm{H}=31,66 \pm 0,721 \mathrm{~cm})$, діаметром стебла $(\mathrm{D}=0,09 \pm 0,001 \mathrm{~cm})$, масою та кількістю генеративних органів (W gen=2,21 $\pm 0,152$ г, $\mathrm{N}$ gen $=26,86 \pm 1,271$ шт.).

Відмінною особливістю рослин 3 угруповання Trifolietum (pratensis) alchemillo (submillefolium)-ranunculosum (acris) є те, що вони є найбільш розгалуженими ( $\mathrm{B}=2,86 \pm 0,215$ шт.), мають найбільший діаметр стебла $(\mathrm{D}=0,09 \pm 0,003 \mathrm{~cm})$ та найменшу масу однієї генеративної структури (Wgen $1=0,07 \pm 0,003$ г).

Рослини 3 фітоценозу Trifolietum (repentis) dauceto (carota) alchemillosum (submillefolium) вирізняються найбільшою площею одного листка $\left(a=2,33 \pm 0,092 \mathrm{~cm}^{2}\right)$, а також співвідношенням між площею листків та масою рослини ( $\left.\mathrm{LAR}=3,34 \pm 0,195 \mathrm{~cm}^{2} / \Gamma\right)$, співвідношенням між площею листкової поверхні та діаметром $\left(\mathrm{ADR}=325,39 \pm 25,925 \mathrm{~cm}^{2} / \mathrm{cm}\right)$. При цьому в них формується найменша кількість генеративних структур ( $\mathrm{N}$ gen $=17,40 \pm 0,735$ шт.), і рослини мають найменші значення репродуктивного зусилля $(\mathrm{RE} 1=17,42 \pm 0,871 \%, \mathrm{RE} 2=5,42 \pm 0,363 \%)$.

Особини 3 угруповання Trifolietum (pratensis) alchemillosum (submillefolium) вирізняються найменшими величинами маси одного листка (WL1 $=0,19 \pm 0,020$ г), фотосинтетичного зусилля $(\mathrm{LWR}=0,26 \pm 0,021$ г/г) та співвідношення між висотою та діаметром $(\mathrm{HDR}=325,76 \pm 19,923$ $\mathrm{cm} / \mathrm{cm})$. Разом із тим їм приманні найбільші значення маси однієї генеративної структури (Wgen $1=0,10 \pm 0,013$ г) та репродуктивного зусилля $(\mathrm{RE} 1=28,98+1,818 \%)$.

Особини $з$ угруповання Trifolietum (pratensis) elytrigiosum (repentis) є найбільшими за показниками співвідношення між висотою та фітомасою $(\mathrm{HWR}=4,51 \pm 0,161 \quad \mathrm{~cm} / \Gamma), \quad$ висотою $\quad$ та діаметром $\quad(\mathrm{HDR}=480,83 \pm$ $\pm 21,430 \mathrm{~cm} / \mathrm{cm})$, а також репродуктивного зусилля (RE2 $=14,21 \pm 1,152 \%)$. При цьому вони $є$ найменшими за величинами комплексу показників, які характеризують вагу рослин та їхніх окремих органів (загальною масою

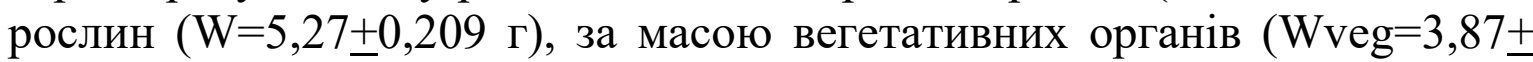
$\pm 0,207$ г), масою листків $(\mathrm{WL}=1,58 \pm 0,178 \quad$ г), масою стебла (Wst $=1,89 \pm 0,060$ г), масою генеративних (W gen $=1,40 \pm 0,057 г$, W gen $1=$ $=0,07 \pm 0,002 \quad$ г) органів, а також площею листкової поверхні $\left(\mathrm{A}=10,44 \pm 0,650 \quad \mathrm{~cm}^{2}\right)$, площею одного листка $\left(a=1,35 \pm 0,077 \quad \mathrm{~cm}^{2}\right)$, кількістю листків ( $\mathrm{NL}=7,80 \pm 0,367$ шт.), діаметром стебла $(\mathrm{D}=0,05 \pm$ $\pm 0,003 \mathrm{~cm})$, висотою $(\mathrm{H}=23,53 \pm 0,608 \mathrm{~cm})$, співвідношенням між площею листків та масою рослини $\left(\mathrm{LAR}=2,00 \pm 0,131 \mathrm{~cm}^{2} / \Gamma\right)$, співвідношенням між площею листкової поверхні та діаметром $\left(\mathrm{ADR}=208,87 \pm 11,039 \mathrm{~cm}^{2} / \mathrm{cm}\right)$.

Угруповання, в яких репрезентовано досліджувані популяції Centaurium erythrea, відрізняються між собою за домінантами. У чотирьох $з$ них домінантом $є$ Trifolium pratense L., у двох - Trifolium 
repens L. Окрім того, фітоценози 3 домінуванням Trifolium repens мають дещо вищій рівень зволоження. Проведений аналіз засвідчив, що зазначена відмінність у домінантах та певною мірою в рівні зволоження проявила статистично достовірний вплив (за сили впливу 4,9-37,7\%) на величини майже всіх морфопараметрів Centaurium erythrea (за винятком трьох: кількості бічних пагонів, маси одного генеративного органу та співвідношення між висотою та фітомасою) (табл. 4). При цьому в статичних метричних морфопараметрів (за винятком маси генеративних органів, співвідношення між висотою та фітомасою, співвідношення між висотою та діаметром, репродуктивного зусилля (RE1, RE2) найбільші значення припадають на угруповання, де домінантом є Trifolium repens (рис. 4). Відмінність у видах-домінантах найбільше вплинула на показники репродуктивного зусилля (RE1-37,7\%; RE2-37,6\%), співвідношення між площею листкової поверхні та діаметром $(29,0 \%)$, фотосинтетичного зусилля $(28,8 \%)$. Серед угруповань із домінуванням Trifolium pratense найменш сприятливими для рослин виявилися угруповання зі співдомінуванням Elytrigia repens L. (угруповання Trifolietum (pratensis) elytrigiosum (repentis).

Таблиця 4

Вплив видового складу домінантів на величини морфопараметрів рослин Centaurium erythrea

\begin{tabular}{|c|c|c|c|}
\hline Морфопараметр & $\begin{array}{c}\text { Критерій } \\
\text { Фішера }\end{array}$ & Довірчий рівень & $\begin{array}{c}\text { Сила впливу } \\
\text { чинника, \% }\end{array}$ \\
\hline W & 9,059 & $0,003410^{*}$ & 9,3 \\
\hline W veg & 25,977 & $0,000002^{*}$ & 22,8 \\
\hline WL & 25,183 & $0,000003^{*}$ & 22,3 \\
\hline W st & 15,338 & $0,000177^{*}$ & 14,8 \\
\hline WL1 & 15,916 & $0,000137^{*}$ & 15,3 \\
\hline A & 9,955 & $0,002196^{*}$ & 10,2 \\
\hline B & 2,983 & 0,087649 & 3,3 \\
\hline NL & 22,990 & $0,000007^{*}$ & 20,7 \\
\hline$a$ & 23,903 & $0,000005^{*}$ & 21,4 \\
\hline H & 5,393 & $0,022520^{*}$ & 5,8 \\
\hline D & 4,578 & $0,035153^{*}$ & 4,9 \\
\hline W gen & 6,104 & $0,015415^{*}$ & 6,5 \\
\hline W gen1 & 0,022 & 0,881232 & 0,1 \\
\hline N gen & 21,302 & $0,000013^{*}$ & 19,5 \\
\hline LAR & 23,857 & $0,000005^{*}$ & 21,3 \\
\hline LWR & 35,669 & $0,000000^{*}$ & 28,8 \\
\hline HWR & 13,333 & $0,000442^{*}$ & 13,2 \\
\hline ADR & 36,013 & $0,000000^{*}$ & 29,0 \\
\hline HDR & 3,487 & 0,065182 & 3,8 \\
\hline RE1 & 53,139 & $0,000000^{*}$ & 37,6 \\
\hline RE2 & 53,270 & $0,000000^{*}$ & 37,7 \\
\hline & & & \\
\hline
\end{tabular}




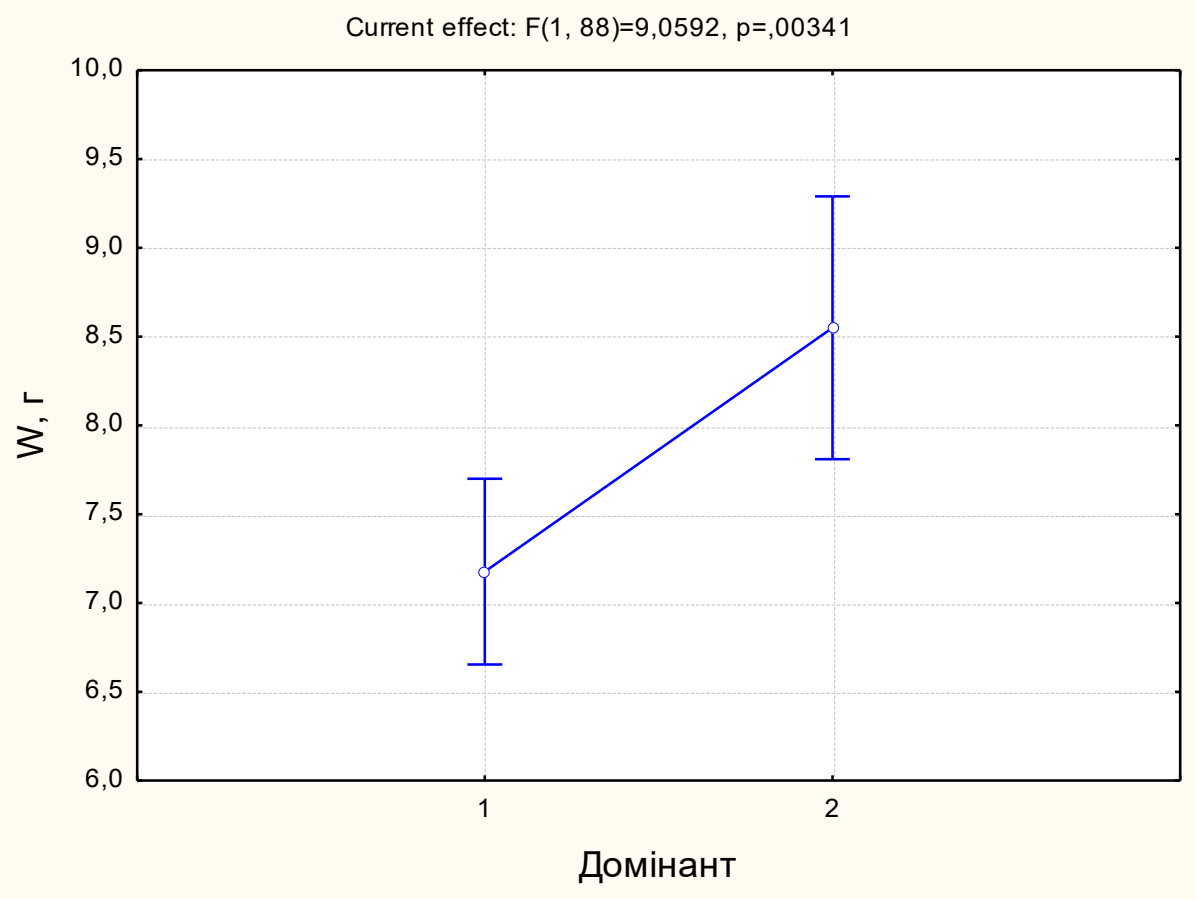

A

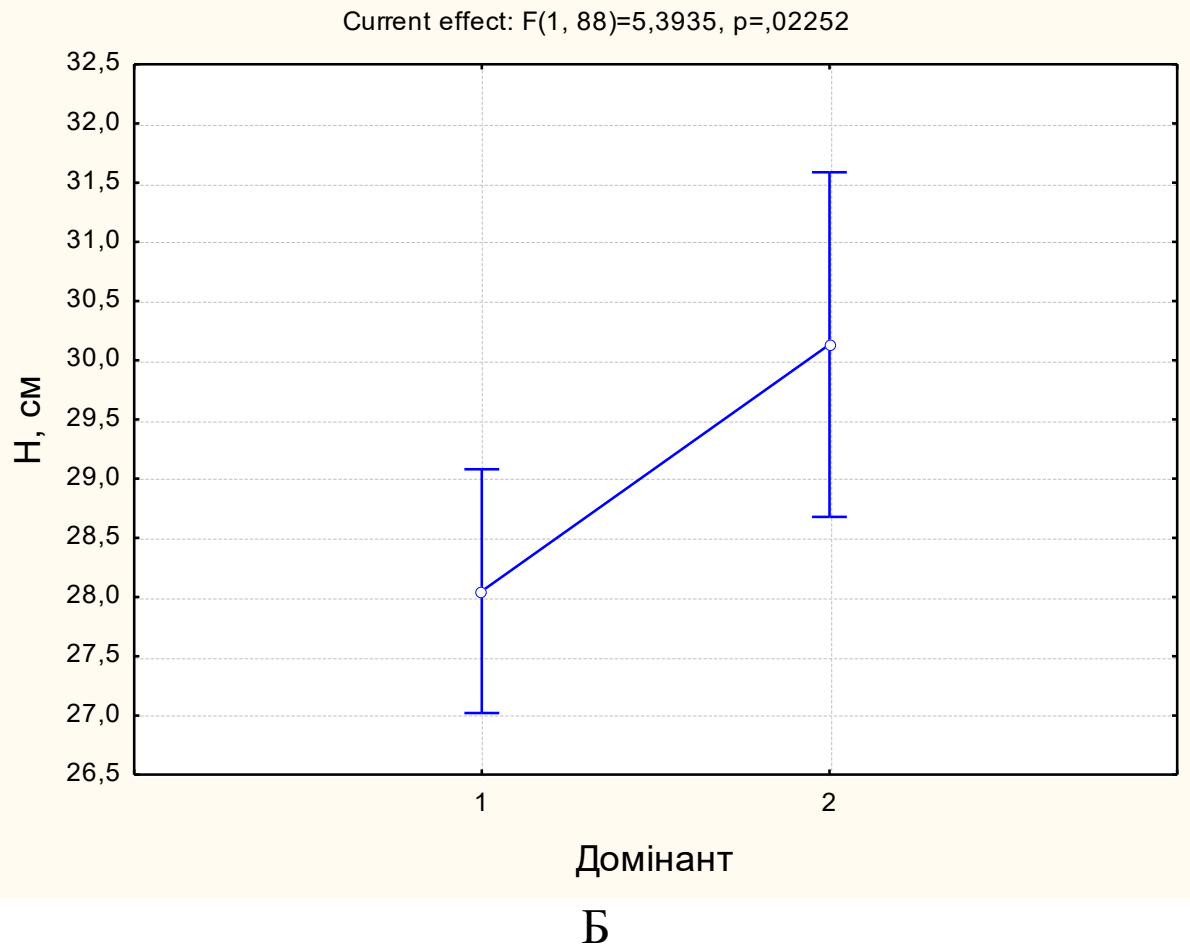

Рис. 4. Зміна величин морфопараметрів рослин Centaurium erythrea на тлі різних домінантів фітоценозів (1 - Trifolium pratense L., 2 - Trifolium repens L.) 
За результатами вивчення стану популяцій Centaurium erythrea в досліджених угрупованнях статистично достовірної та чітко вираженої залежності між величинами морфопараметрів та проективним покриттям фітоценозу не виявлено.

Встановлено, що у популяцій Centaurium erythrea показники IDSS варіюють у діапазоні 28,0-44,0\% (табл. 5). Тобто в їхньому складі репрезентовано рослини, розмірні величини яких відповідають 7-11 варіантам сполучення розмірних класів висоти та площі листкової поверхні. Найвищим рівнем IDSS (44\% - 11 варіантів сполучення розмірних класів) вирізняється популяція з угруповання Trifolietum (repentis) dauceto (carota)-alchemillosum (submillefolium) (рис. 5). Вона сформована із рослин, розмір яких за висотою відповідає I-III класам, а за площею листкової поверхні - I-IV класам. Найбільшу частку (по 13,33\%) у цій популяції становлять рослини, величини яких відповідають сполученням розмірних класів: I-III, II-III, III-II, III-III.

Високі значення IDSS (40\% - 10 варіантів сполучення) притаманні й популяції 3 угруповання Trifolietum (pratensis) alchemillosum (submillefolium). У ній репрезентовано особини II-IV класів висоти та II-V класів за площею листкової поверхні. Найбільшою $є$ частка рослин, розмір яких відповідає $\mathrm{V}$ класу як за висотою, так і за площею.

Досить значні показники IDSS $(36,0 \%$ - по дев'ять варіантів сполучення розмірних класів) притаманні популяціям 3 угруповань Trifolietum (pratensis) plantageto (lanceolata)-alchemillosum (submillefolium) та Trifolietum (pratensis) alchemillo (submillefolium)-ranunculosum (acris). В обох цих фітоценозах зростають рослини I-III класів висоти. Однак вони мають певну відмінність у розподілі величин площі листкової поверхні. У першому із цих угруповань репрезентовано рослини I-IV класів за площею листової поверхні, в другому - рослини II-V класів. В угрупованні Trifolietum (pratensis) plantageto (lanceolata)-alchemillosum (submillefolium) найбільшою $(20,0 \%)$ є частка рослин III класу за висотою та IV класу за площею.

В угрупованні Trifolietum (pratensis) alchemillo (submillefolium)ranunculosum (acris) найбільшу питому вагу (26,66\%) мають рослини II класу за висотою та IV за площею.

В угрупованні Trifolietum (repentis) tanacetosum (vulgaris) величини IDSS знижені до 32,0\% (вісім варіантів сполучення розмірних класів). Тут зростають особини I-III класів висоти та I-IV за площею листкової поверхні. Найбільшу (20\%) частку становлять рослини III класу, як за висотою, так і за площею листкової поверхні. 


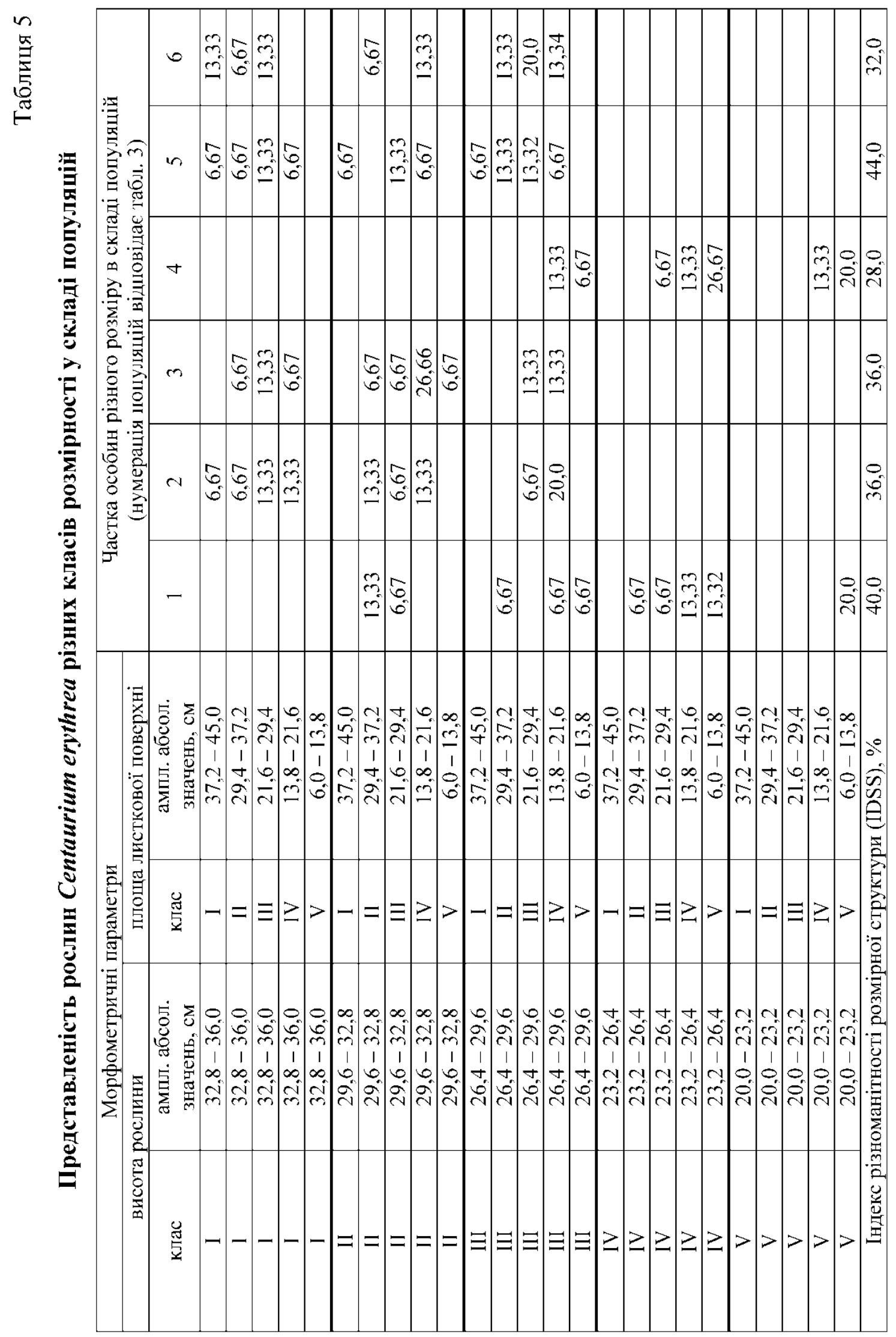




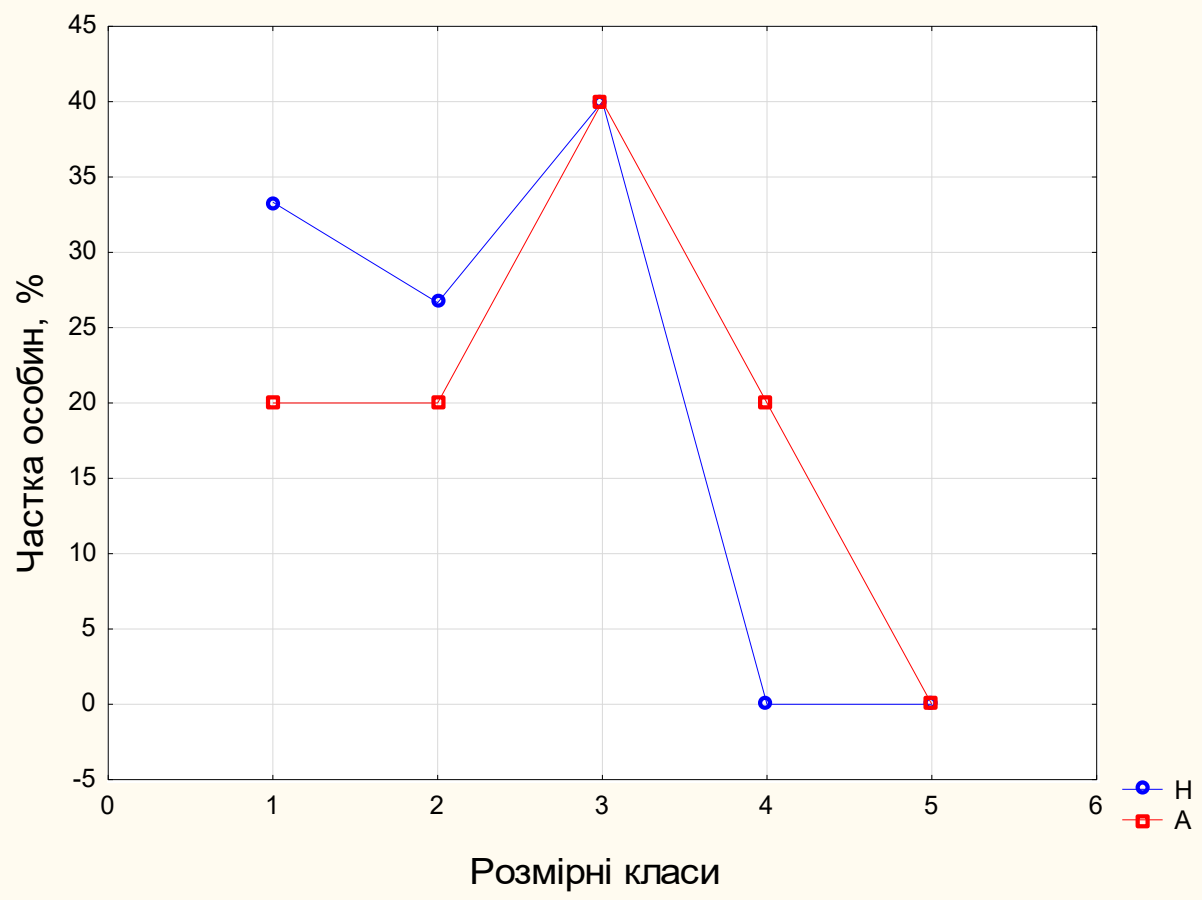

Рис. 5. Розмірні спектри популяції Centaurium erythrea в угрупованні Trifolietum (repentis) dauceto (carota)-alchemillosum (submillefolium)

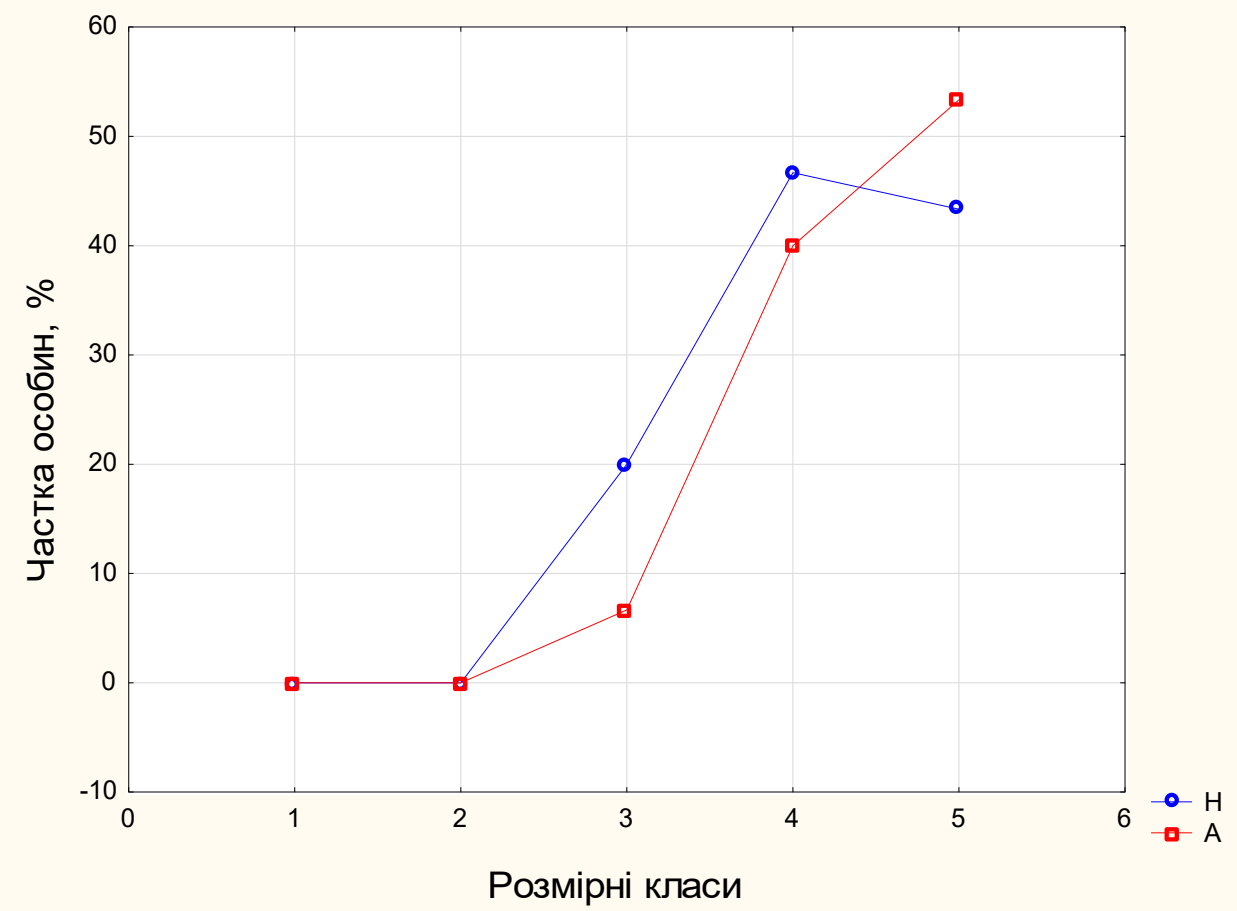

Рис. 6. Розмірні спектри популяції Centaurium erythrea в угрупованні Trifolietum (pratensis) elytrigiosum (repentis)

Популяції Centaurium erythrea 3 угруповання Trifolietum (pratensis) elytrigiosum (repentis) (рис. 6.) мають найменш різноманітну розмірну 
структуру: IDSS $=28,0 \%$, що відповідає семи варіантам сполучення розмірних класів. У ньому наявні рослини III-V класів, як за висотою, так і за площею. Найбільшою $(26,67 \%) \in$ частка рослин, розмір яких відповідає IV класу за висотою та V за площею.

У популяцій Centaurium erythrea в значеннях індексу різноманітності розмірної структури (IDSS) не проявилася чітко виражена тенденція щодо змін величин за досліджуваними угрупованнями. Хоча найменш різноманітною розмірна структура $\epsilon$ у фітоценозі, в якому співдомінантом виступає Elytrigia repens (угруповання Trifolietum (pratensis) elytrigiosum (repentis)). Разом із тим у фітоценозах із домінуванням Trifolium pratense, що мають дещо нижчий рівень зволоження, показники різноманітності розмірної структури виявилися меншими, ніж у фітоценозах із домінуванням Trifolium repens: $28,0-40,0 \%$ проти $32,0-44,0 \%$.

\section{ВИСНОВКИ}

Результати дослідження розмірних ознак рослин та популяцій Centaurium erythrea засвідчили, що в них залежно від умов місцезростань мають місце статистично достовірні зміни абсолютного розміру та архітектоніки рослин. Величини морфопараметрів проявляють високий ступінь ознак специфічності щодо динаміки своїх показників за місцезростаннями, у підсумку в кожному із фітоценозів формуються рослини 3 характерними ознаками габітусу та морфоструктури. При цьому чітко виділяються угруповання, в яких зростають рослини Centaurium erythrea iз комплексом найбільших та найменших значень розмірних величин. Доведено, що розмірні ознаки рослин Centaurium erythrea статистично достовірно залежать від характеру фітоценотичного оточення та певною мірою - від вологості грунту. У фітоценозах із домінуванням Trifolium pratense, що мають дещо нижчий рівень зволоження, величини більшості морфопараметрів були меншими, ніж у фітоценозах із домінуванням Trifolium repens.

У складі популяцій Centaurium erythrea представлені рослини, величини морфопараметрів яких відповідають декільком (від трьох до п'яти) розмірним класам, що здебільшого формують континуальний ряд. Особливості розмірної структури популяцій проявляються через: а) відмінності в розподілі рослин за класами розмірності; б) відмінності в розподілі рослин за сполученнями різних пар класів; в) абсолютні величини індексу різноманітності розмірної структури (IDSS).

Загалом, у популяцій Centaurium erythrea зареєстровано високі величини індексу різноманітності розмірної структури (IDSS). У динаміці величин IDSS, як і абсолютних значень морфопараметрів, зареєстрована зміна значень залежно від фітоценотичного оточення популяції: у фітоценозах із домінуванням Trifolium pratense показники 
різноманітності розмірної структури загалом виявилися меншими, ніж у фітоценозах із домінуванням Trifolium repens: 28,0-40,0\% проти $32,0-44,0 \%$.

\section{АНОТАЦІЯ}

Представлено результати дослідження морфоознак рослин та розмірної структури ценопопуляцій Centaurium erythrea, сформованих у різних місцезростаннях заплавних лук Кролевецько-Глухівського геоботанічного району. Досліджено шість ценопопуляцій Centaurium erythrea, які входять до складу різних угруповань. У процесі роботи використано морфометричний аналіз та комплекс методів статистичноматематичного опрацювання даних. Результати дослідження розмірних ознак рослин та популяцій Centaurium erythrea засвідчили, що в них, залежно від умов місцезростань, мають місце статистично достовірні зміни абсолютного розміру та архітектоніки рослин. Для абсолютної більшості розмірних величин зареєстровані відмінності у величинах морфопараметрів у рослин із різних угруповань $\epsilon$ статистично достовірними. У складі популяцій Centaurium erythrea представлені рослини, величини морфопараметрів яких відповідають декільком (від 3 до 5) розмірним класам, що здебільшого формують континуальний ряд. Загалом у популяцій Centaurium erythrea зареєстровано високі величини індексу різноманітності розмірної структури (IDSS).

\section{ЛІТЕРАТУРА}

1. Атлас ареалов и ресурсов лекарственных растений СССР. Москва : ГУГК, 1980. $243 \mathrm{c.}$

2. Заповідні скарби Сумщини / за ред. Т.Л. Андрієнко. Суми : Джерело, 2001. 208 c.

3. Злобин Ю.А. Популяционная экология растений: современное состояние, точки роста. Сумы : Университетская книга, 2009. 263 с

4. Злобин Ю.А. Принципы и методы изучения ценопопуляций растений. Казань, 1989. 146 с.

5. Карманова И.В. Математические методы изучения роста и продуктивности растений. Москва : Наука, 1976. 222 с.

6. Методы полевого изучения лекарственных растений : учебнометод. пособие для студентов биологического факультета / А.С. Кашин и др. Саратов, 2007. 27 с.

7. Коропачинский И.Ю. Роль ботанических садов в охране биологического разнообразия России. Сиб. экол. журн. 1997. Т. 4. № 1. C. 7-12.

8. Полевая геоботаника. Москва-Ленинград : Наука, 1964. Т. 3. 530 с. 
9. Прохоров А.А. Экологические проблемы сохранения биологического разнообразия на примере генетических ресурсов ботанических садов России : автореф. дис. ... докт. биол. наук. Петрозаводск, 2004. 46 с.

10. Сикура И.И., Антонюк Н.Е., Пироженко А.А. Интродуцированные лекарственные растения ; под ред. А.М. Гродзинского. Київ, 1983. C. 54-60.

11. Скляр В.Г. Розмірна структура деревостанів сосни звичайної в лісах Новгород-Сіверського Полісся. Ученые записки Таврического национального ун-та им. В.И. Вернадского. Серия «Биология, химия». 2011. T. 24 (63). № 4. С. 292-302.

12. Скляр В.Г. Узагальнюючі моделі вертикальної структури деревостанів лісових фітоценозів Лівобережного Полісся України. Вісник Запорізького національного університету. Біологічні науки. 2016. № 1. C. 176-184.

13. Товстуха Є.С. Фітотерапія. Київ, 1990. С. 68-69.

14. Шерстюк М.Ю. Морфометричні ознаки Oxycoccus palustris Pers. у болотних та лісоболотних фітоценозах Українського Полісся. Науковий вісник Східноєвропейського начіонального університету імені Лесі Украӥнки. Серія: Біологічні науки. 2016. № 7 (332). С. 78-83.

15. Шерстюк М.Ю. Ценопопуляції Ledum palustre (Ericaceae) у лісових і лісоболотних фітоценозах Новгород-Сіверського Полісся. Украйнський ботанічний журнал. 2017. Т. 74. № 1. С. 37-44.

16. Шерстюк М.Ю., Попович С.Ю. Заповідні дендросозоавтохтони Українського Полісся : монографія. Київ : ЦП Компринт, 2018. 272 с.

17. Якубенко Б.С., Григора I.М. Популяція і фітоценоз. Методи вивчення популяцій. Київ : НАУ, 2003. 35 с.

18. Fabricant DS, Farnsworth NR. The value of plants used intraditional medicine for drug discovery. Environ HealthPerspect. 2001. Vol. 109. P. 69-75

19. Hunt R. Plant growth analysis. London : Arnold, 1978. 67 p.

20. Joy P.P., Thomas J., Mathew S. Medicinal plants. Tropical horticulture. 2001. V. 2. P. 449-632.

21. Medicinal plants research in Asia. Volume 1. The framework and project workplans (Pons B.A., Kanniah J., Young L.S. et al., eds.). International plant genetic resources institute-Regional office for Asia and Oceania (IPGRI-APO). Serdang, Selangor DE, Malaysia, 2004.

22. Skliar V.G. The dimensional characteristics of the middle undergrowth Quercus robur in forests of Novgorod-Sivers'k Polissia (Ukraine). European Applied Sciences. 2013. № 7. 19-20.

23. Skliar V., Sherstuk M. Size structure of phytopopulations and its quantitative evaluation. Eureka: Life Sciences. 2016. № 1. P. 9-15. 
24. Yarnell E., Abascal K. Dilemmas of traditional botanicalresearch. Herbal Gram. 2002. № 55. P. 46-54.

25. Dimensional features population of some species medicinal plants in conditions of northern Eastern Ukraine / I. Zubtsova at al. AgroLife Journal. 2019. № 8 (2). 191-201.

Information about authors:

Zubtsova I. V.,

Assistant at the Department of Ecology and Botany

Sumy National Agrarian University

160, Herasym Kondratiev str., Sumy, 40021, Ukraine

Skliar V. G.,

Doctor of Biology, Professor,

Head of the Department of Ecology and Botany

Sumy National Agrarian University

160, Herasym Kondratiev str., Sumy, 40021, Ukraine 